\title{
The Influence of Brand Image Towards the Purchase Intention on Family Car
}

\author{
Lisnawati ${ }^{1, *}$ Lili Adi Wibowo ${ }^{2}$ D.F. Suhendro ${ }^{3}$
}

\author{
${ }^{1}$ Universitas Pendidikan Indonesia \\ ${ }^{2}$ Universitas Pendidikan Indonesia \\ ${ }^{3}$ Universitas Pendidikan Indonesia \\ *Corresponding author.Email: lisnawati@upi.edu
}

\begin{abstract}
Car is a very needed transportation and much demand by the community. Competition of business automotive in Indonesia is attractive. The purpose of this research is how the influence of the brand image on purchase intention. The type of this research are verificative. The method used is cross sectional with a population size of 588 and a sample of 238 respondents. The method used is simple random sampling. The findings in this research show that the brand image is high in category, while the purchase intention is low. Brand image has a positive and significant influence on purchase intention.
\end{abstract}

Keywords: Brand Image, Purchase Intention.

\section{INTRODUCTION}

The automotive industry has experienced significant development in recent years. It can be seen from the increase in sales of automotive products to the emergence of various new brands in the automotive industry in the country. Data from the Association of Indonesian Motorcycle Industry (AISI) compiled from the Ministry of Industry shows that motorcycle sales in 2019 grew 1.6 percent or 6,487,460 units, an increase from the previous $6,383,108$ units [1]. The automotive industry, especially cars, is still considered promising. This is influenced by several factors including the increasing public need and interest in cars, incentive policies for the automotive industry, massive toll road infrastructure development, and the implementation of the Making Indonesia 4.0 roadmap, which makes the automotive industry one of the five manufacturing sectors that receive development priorities.

Purchase intention is a behavior that appears in response to an object that shows the consumer's desire to make a purchase [2]. Purchase intention is the initial condition that determines the consumer's decision to choose a product or service. Consumer purchasing decisions are based on purchase intention which can change under the influence of price or perceived quality and value, in addition, consumer interest is influenced by internal or external motivations during the buying process [3].

Purchase intention in the technology industry is a clue that plays an important role in future purchases that will be made by consumers [4]. Consumers must determine their own preferences carefully and also selectively, where producers or business people are currently competing to issue the best products to meet consumer needs and desires, especially in the automotive industry which has intense competition. Competition between the automotive industry, especially cars, is marked by the presence of cars with the Low Multi Purposes Vehicle (Low MPV) segment. Referring to Gaikindo's statistical data, during 2019, the Low MPV segment was the type of family car whose sales were the most in demand because it targeted the middle class who did dominate car consumers in Indonesia.

Various strategies are carried out by Family Car to increase consumer purchase intention by improving the quality of products that have better features and more affordable prices than its competitors. However, due to the stigma against Chinese brand products, strategies to improve the Family Car brand image in the eyes of consumers need to be optimized [5]. This is in line with the opinion of [6] that purchase intention is formed from consumer attitudes towards products which consist of trust in a brand in addition to the ability to buy products. The brand image of a company is an important 
component to foster purchase intention. Brand image tells about mental and brand representations based on consumers' individual beliefs, ideas and impressions [7]. According to [8], brand image is a consumer's perception of a brand as a reflection of the associations that exist in the human mind, which is always remembered for the first time when hearing a slogan and embedded in consumers' memories. Meanwhile, according to [9], brand image is a description of associations and consumer beliefs about certain brands. So it can be concluded that the brand image is the perception and belief in a brand that is embedded in the memory of consumers. If a brand has a good impression in the eyes of consumers, then the brand has succeeded in building a good brand image in the eyes of consumers.

Research conducted by [10] on the sale of Japanese brand cars in Bangkok, shows that the things that affect purchase intention are brand awareness, quality, and brand loyalty. While purchase intention in the automotive industry in Indonesia has been investigated by [11] at PT Agung Toyota Denpasar. The results showed that service quality, product quality, and brand image that are strongly attached to consumers have a positive effect on purchase intention.

Based on stated above, the researcher wants to investigate further about brand image and its influence on purchase intention in Family Car Confero cars as one of the Low MPV car segments.

Strategic marketing is the process of developing a strategic marketing process, taking into account the constantly changing business environment according to customer needs and aiming to provide superior value. The focus of strategic marketing is more centered on organizational performance than efforts to increase sales. Strategic marketing connects the organization with the environment and views marketing as the responsibility of the entire business [12].

Strategic marketing consists of several processes including: 1) markets, segments, and customer value, 2) designing strategic market driven, 3) market driven program development and 4) implementing and managing market-driven strategy [12]. One of the processes in strategic marketing is market-driven program development which refers to market targeting and positioning strategies to guide strategy choices in marketing programs. The marketing strategy applies a positioning strategy using a marketing mix program consisting of: 1) strategic brand management, 2) valuechain, 3) pricing and 4) promotion [12].

Strategic brand management involves the design and implementation of marketing programs and activities to build, measure, and manage brand equity [13]. Brand is an intangible asset that plays an important role for the company because it can bring several advantages and is the basis of the company's competitive advantage [14].
The company's competitive advantage in the form of high brand equity can provide opportunities for companies to be successful and resistant to competitors' promotional pressures [14].

The main steps in strategic brand management consist of: 1) identifying and developing brand plans, 2) designing and implementing brand marketing programs, 3 ) measuring and interpreting brand performance, and 4) growing and sustaining brand equity [13]. The first step of strategic brand management begins with identifying and conducting a clear understanding of the brand concept and how the brand should be positioned against competitors. The next step after identifying the brand, carried out the development of brand planning with the aim of strengthening the brand.

The concept of Brand Equity is an asset that can provide its own value in the eyes of its customers, can assist customers in interpreting, processing, and storing information related to these products and brands. Brand equity can affect consumer confidence in making purchasing decisions on the basis of past experience in use or proximity, associations with various brand characteristics [13]. Brand equity consists of: 1) Brand Awareness, 2) Brand Association, 3) Perceived Quality, 4) Brand Image, and 5) Brand Loyalty [13]

The indicator develops product lines by utilizing the positive brand image that has been formed against the old product brand. The thing that the company must pay attention to is how to maintain and improve the brand image [15]. Building a positive brand image can be achieved with a strong marketing program for the product, which is unique and has advantages that are highlighted, which distinguishes it from other products. A good combination of supporting elements can create a strong brand image for consumers. this is an indicator of brand equity that is directly related to consumer perceptions of the identity of a product [13]. Brand image has dimensions consisting of: Favorability of Brand Association, Strength of Brand Association, and Uniqueness of Brand Association [13].

Marketing consists of various sciences, one of which is consumer behavior. Consumer behavior is the study of how individuals, groups, and organizations select, buy, use, and spend goods, services, ideas, or experiences to satisfy their needs and wants. Consumer behavior is the behavior shown by consumers in searching for, buying, using, evaluating and disposing of products that are expected to satisfy the needs of life [16]. One of the concepts of consumer behavior is the purchasing decision process. The consumer buying decision process is very detailed to answer questions about what consumers buy, where they buy, and why they buy. Marketers can study actual consumer purchases to discover what they are buying, where, and for how much. But learning about why a consumer's buying behavior occurs is not easy, the 
answer is often locked deep in the minds of consumers [17].

According to [18] the purchasing decision process is divided into 3 main stages, namely: Pre purchase, Service Encounter Stage, and Post Encounter Stage. In the prepurchase stage of the purchasing decision process, services are more complex than goods because they involve a series of combined factors and activities [18]. This pre-purchase stage begins with the emergence of a need, awareness of potential customers of a need, followed by seeking information and evaluating a number of alternatives to decide whether the customer will buy a service. Then according to [18] the prepurchase stage consists of: 1) the emergence of a need, 2) information search, 3) evaluation of alternatives, 4) purchase intention, and 5) purchasing decisions.

According to [19], purchase intention is the tendency of consumers to buy a brand or take actions related to purchases as measured by the level of possibility of consumers making purchases. Purchase intention according to [16]. Consumers can be influenced by perceptions in consumers' minds about brand image, store name, and target price. According to [20] through brand image, consumers can form purchase intention based on factors such as expected income, expected price, and expected product benefits. There are 4 dimensions of purchase intention, namely: 1) Transactional Interest, 2) Referential Interest, 3) Preferential Interest, and 4) Explorative Interest [21].

In discussing the relationship between brand image and purchase intention, researchers explain that brand image has a direct effect on purchase intention [22, 23]. It was found in subsequent research that brand image has a positive effect on purchase intention [22].

\section{METHODS}

1) The approach used in this study is a marketing management approach, especially regarding purchase intention. The object of research as the independent variable is brand image with the dimensions of favorability of brand association, strength of brand association, and uniqueness of brand association. The object of research that becomes the dependent variable is purchase intention which includes transactional interest, referential interest, preferential interest and exploratory interest. Respondents in this study were family consumers in Indonesia. The selection of families as respondents was based on the target market for Low MPV cars in Indonesia as a multifunctional family vehicle. Based on the time the method used in this study is a cross sectional method. The approach taken in this research is quantitative research methods. Based on the calculation results, the number of samples used in this study were 238 respondents representing 238 families. Data processing techniques refer to the method used to collect the data needed for research. Literature study, which is a data collection technique by studying papers, books, journals, articles and websites to obtain information related to the variables studied which consist of brand image and purchase intention.

2) Dissemination of a list of statements in the questionnaire online using the google form or directly to the respondents. In the questionnaire, the researcher put forward several statements that reflect the measurement of the indicator variable brand image and variable purchase intention. Furthermore, the respondent chooses an alternative answer that has been provided which is considered the most appropriate to represent the conditions felt by the respondent. The steps for preparing the questionnaire are as follows:

a) Compile a list of statements. The type of instrument used in the questionnaire is a closed instrument, namely a list of written statements accompanied by alternative answers provided, so that respondents only choose the available answers.

b) Determine the scoring for each item using an interval scale (scemantic differential scale 1:7)

c) The questionnaire was created online using a google form and made a copy of the questionnaire for direct submission.

3) Literature study, which is an effort to collect information related to theories that have to do with the problems and variables studied. The literature study was obtained from various sources, namely 1) UPI library, 2) thesis, 3) economic and business journals, 4) print media (magazines), 5) electronic media (internet).

The data analysis technique used is simple linear regression analysis using SPSS 22.0 for windows.

\section{RESULTS AND DISCUSSION}

In this study, correlation analysis (pearson correlation) will be used using SPSS 23.0 software for windows. This coefficient analysis aims to test whether there is a correlation or relationship from the independent variable to the dependent variable. As for finding the correlation coefficient interpretation criteria (see Table 1) will be based on the accuracy proposed by [24]

Table 1.Correlation coefficiency interpretation

\begin{tabular}{|l|l|}
\hline Coefficient Interval & Influence level \\
\hline $0-19,99 \%$ & Very Weak \\
\hline $20 \%-39,99 \%$ & Weak \\
\hline $40 \%-59,99 \%$ & Moderate \\
\hline $60 \%-79,99 \%$ & Strong \\
\hline $80 \%-100 \%$ & Very Strong \\
\hline
\end{tabular}

Based on the results of processing carried out with SPSS 23.0 software for windows, a summary of the output model is obtained from the calculation of the 
Pearson Production Moment correlation coefficient can be seen in Table 2 .

Table 2. Output model summary

\begin{tabular}{|l|l|l|l|l|}
\hline \multicolumn{4}{|l|}{ Model Summary } \\
\hline Mode & R & R Square & Adjusted R Square & Std. Error of the Estimate \\
\hline 1 & .844 & .712 & .711 & 3.620 \\
\hline
\end{tabular}

In Table 2 the SPSS 22.0 summary output model for windows, it can be seen that the correlation or relationship between product placement and interest in using the results is 0.606 (positive). In accordance with the guidelines for providing an interpretation of the correlation coefficient [24], the correlation between brand image and purchase intention is included in the strong category, which is in the interpretation of the correlation coefficient $(0.60-0.79 .99)$ with the Standard Error of Estimate (SEE) of 3,620. Table 3 shows the simple linear regression model of brand image on purchase intention.

Table 3. Simple linear regression model of brand image on purchase intention

\begin{tabular}{|l|l|l|l|l|l|l|}
\hline \multirow{2}{*}{ Model } & \multicolumn{2}{l|}{ Unstandardized Coefficients } & $\begin{array}{l}\text { Standardized } \\
\text { Coefficients }\end{array}$ & t & Sig \\
\cline { 3 - 7 } \multicolumn{2}{|l|}{} & B & Std. Error & Beta & & \\
\hline \multirow{2}{*}{1} & (Constant) & -2.658 & 1.065 & & -2.496 & .013 \\
\cline { 2 - 7 } & Brand Image & .679 & .028 & .844 & 24.180 & .000 \\
\hline
\end{tabular}

Based on Table 3 in column $\mathrm{B}$, the constant values and simple linear regression coefficient values for the independent variables are listed. Based on those values then a simple linear regression model can be determined which is expressed in (1).

$\mathrm{Y}=\mathrm{a}+\mathrm{Bx}$

$Y=-2.658+0.679 X$

Based on the simple linear regression (1), the constant value of -2.568 states that if there is no brand image, then the amount of purchase intention is -2.568 . The regression coefficient on the purchase intention variable is 0.679 , which means that every time there is an increase in the value of purchase intention, there will be an increase in purchase intention of 0.679 . Conversely, if there is a decrease in purchase intention, the brand image will reduce purchase intention by 0.504 one unit value. It can be said that the brand image in the company will affect the level of purchase intention. If the brand image is not conducive, then purchase intention will be low.

In Table 4, it can be seen that the magnitude of $t$ count is 24.180 with $t$ table of 1.97 so that calculated $>t$ table $(24.180>1.97)$ then the decision that can be taken is $\mathrm{H} 0$ is rejected and $\mathrm{Ha}$ is accepted. This means that brand image affects purchase intention.

Table 4. $T$ test calculation result

\begin{tabular}{|l|l|l|l|l|l|l|}
\hline \multicolumn{2}{|l|}{ Model } & \multicolumn{2}{l|}{ Unstandardized Coefficients } & $\begin{array}{l}\text { Standardized } \\
\text { Coefficients }\end{array}$ & t & Sig \\
\cline { 3 - 7 } \multicolumn{2}{|l|}{} & B & Std. Error & Beta & & \\
\hline \multirow{2}{*}{11} & (Constant) & -2.658 & 1.065 & & -2.496 & .013 \\
\cline { 2 - 7 } & Brand Image & .679 & .028 & .844 & 24.180 & .000 \\
\hline
\end{tabular}

The $\mathrm{F}$ test is carried out by comparing the significance of Fcount with Ftable with the following conditions:
- $\quad \mathrm{H} 0$ is accepted and Ha is rejected if Fcount Ftable for $=0.05$. 
- $\quad \mathrm{H} 0$ is rejected and $\mathrm{Ha}$ is accepted if Fcount > Ftable for $=0.05$

Based on the output in Table 5, it is known that the Fcount value is 584,681 with a p-value ( $\mathrm{sig}$ ) of 0.000 . With $=0.05$ and degrees of freedom df $2=n-k=237-$
$1=236$ and df $1=\mathrm{k}-1=2-1=1$, then Ftable 3.05 is obtained. Due to the value of Fcount > Ftable $(584,681>$ $3.05)$, then $\mathrm{HO}$ is rejected and $\mathrm{Ha}$ is accepted, meaning that purchase intention has a significant effect on brand image.

Table 5. F test calculation result

\begin{tabular}{|l|l|l|l|l|l|l|}
\hline \multicolumn{2}{|l|}{ ANOVA } \\
\hline \multicolumn{2}{|l|}{ Model } & Sum of squares & Df & Mean square & F & Sig. \\
\hline \multirow{3}{*}{1} & Regression & 7663.708 & 1 & 7663.708 & 584.681 & $.000 \mathrm{~b}$ \\
\cline { 2 - 7 } & Residual & 3093.372 & 236 & 13.108 & & \\
\cline { 2 - 7 } & Toral & 10757.080 & 237 & & & \\
\hline
\end{tabular}

Table 6 shows the determination coefficient of brand image on purchase intention.

Table 6. Determination coefficient of brand image on purchase intention

\begin{tabular}{|l|l|l|l|l|}
\hline \multicolumn{4}{|l|}{ Model Summary } \\
\hline Mode & R & R Square & Adjusted R Square & Std. Error of the Estimate \\
\hline 1 & .844 & .712 & .711 & 3.620 \\
\hline
\end{tabular}

Equation (2) shows calculation of coefficient of determination from brand image to purchase intention.

$$
\begin{aligned}
\mathrm{KD} & =\mathrm{r} 2 \times 100 \% \\
& =\mathrm{r} 2 \times 100 \% \\
& =(0.844) 2 \times 100 \% \\
& =0.712336 \times 100 \% \\
& =71.2336=71 \%
\end{aligned}
$$

From the results of calculating the coefficient of determination for brand image onpurchase intention is $71 \%$, in other words purchase intention is strongly influenced by $71 \%$ by brand image while $29 \%$ is influenced by other factors outside of brand image.

Based on the results of research conducted by researchers regarding the effect of brand image on purchase intention in Wuling Confero cars, it can be concluded that brand image has a relationship with purchase intention. The magnitude of the relationship that occurs is shown by the correlation between brand image and purchase intention which results in 0.606 this is in accordance with the interpretation number of the correlation coefficient [24], then the relationship between brand image and purchase intention is included in the strong category $(0.60-0)$. ,79.99) with a Standard Error of Estimate (SEE) of 5,615 for the purchase intention variable.
Based on the Standard Deviation (STD) number, purchase intention shows that this number is greater than the SEE figure of purchase intention of 5.615, this means that (SEE) is good to be used as a predictor in determining purchase intention, where a good number to be used as a predictor of the dependent variable must be smaller than the Standard Deviation number (SEE $<\mathrm{STD})$, the smaller the SEE will make the regression more precise in predicting the dependent variable.

Based on the simple linear regression, the constant value of -2.568 states that if there is no increase in brand image $(X=0)$, then the amount of purchase intention is 2.568. The regression coefficient on the brand image variable is 0.679 one unit value, which means that every time there is an increase in brand image, there will be an increase in purchase intention by 0.679 one unit value and vice versa if there is a decrease in brand image, it will decrease purchase intention by 0.504 one unit value. These results indicate that brand image affects purchase intention by $71 \%$. While the influence from outside which is not examined by $29 \%$ is influenced by other variables that are not included in this study. This is in accordance with research conducted by [25] which says that brand image has a direct effect on purchase intention.

Based on the results of the study, it was found theoretical in the form of the influence of brand image on purchase intention according to research conducted by 
[26] that the brand image factor is a factor that can affect purchase intention. Previous research conducted by [27] suggests that there is a relationship between brand image and purchase intention. Through the relationship between brand image and purchase intention, it can be seen the influence between brand image and purchase intention. Consumer desire or consumer purchase intention will be higher with products that have a good brand image [28].

\section{CONCLUSIONS}

The results of the study state that brand image affects purchase intention, but with the explanation above the influence of brand image is significant, therefore it is necessary to improve strategies to strengthen brand image so that the value that affects purchase intention will be significant. Purchase intention will grow with a good image in the minds of consumers through the company's strategy, one of which is product innovation.

\section{REFERENCES}

[1] AISI, "Association of Indonesia Motorcycle Industry," AISI, 2020. [Online]. Available: www.aisi.or.id.

[2] P. Kotler and G. Armstrong, "Principles of Marketing," World Wide Web Internet Web Inf. Syst., p. 785, 2010.

[3] B. . Gogoi, "Study of antecedents of purchase intention and its effect on brand loyalty of private label brand of apparel," Int. J. Sales Mark., vol. 3, 2013, no. 2, pp. 73-86, 2013.

[4] P. C. and S. C. Cozby, Method in Behavioral Research, McGraw Hill. 2012.

[5] F. Asty, "Pengaruh Country of Origin Brand (COOB) terhadap keputusan pembelian merek otomotif wuling motors (Studi kasus pada generasi Y di Jakarta Selatan),” 2020.

[6] K.-A. Byun and M. Dass, "An investigation of the effects of product recalls on brand commitment and purchase intention," J. Consum. Mark., vol. 32, no. 1, pp. 1-14, 2015.

[7] H. K. Malik, M. E., Ghafoor, M. M., Iqbal, "Impact of brand image and advertisement on consumer buying behavior," no. 23(1), pp. 117-122, 2013.

[8] P. Kotler and K. L. Keller, Marketing Management, vol. 15E, no. 4. 2016.

[9] F. Tjiptono, "Brand Management \& Strategy," 2015.

[10] M. Thanomsub, "Factors Affecting Consumer's Purchase Intention toward Japanese Car in Bangkok.," 2014.
[11] N. M. Aryadhe, P., \& Rastini, "Kualitas pelayanan, kualitas produk dan citra merek terhadap niat beli ulang di PT Agung Toyota Denpasar," vol. 5(9), pp. 5695-5721., 2016.

[12] Cravens \& Piercy, "Strategic Marketing (10th ed.), New York: Mc Graw Hil. 2013.

[13] K. L. Keller, Strategic Brand Management, vol. 58. 2013.

[14] S. Arora and Neha, "Determinants of customerbased brand equity: A study of public and private banks," Glob. Bus. Rev., vol. 4, no. 17, pp. 905-920, 2016.

[15] P. Kotler and K. L. Keller, Marketing Management. 2012.

[16] L. L. Schiffman, L. G., \& Kanuk, Customer Behavior 8th Edition, New Jersey:Prentice Hall. 2010.

[17] D. Hawkins, D. Mothersbaugh, and R. Best, “Consumer Behavior," 2016.

[18] Lovelock and Jochen Wirtz, Services Marketing: People, Technology, Strategy, 7th edition, no. September. 2016.

[19] A. Hasan, Marketing dan Kasus-kasus Pilihan, Jakarta : PT. Buku Seru. 2013.

[20] P. Kotler and G. Armstrong, Principles of Marketing. 2015.

[21] A. Ferdinand, "Structural equation modeling dalam penelitian manajemen Undip Semarang," 2011.

[22] D. R. A and C. M. Firdausy, "Pengaruh citra merek, persepsi harga dan kualitas produk Honda Brio Satya terhadap minat beli pelanggan di Jakarta," pp. 156-161, 2019.

[23] J. L. M. Tam and J. L. M. Tam, "Customer satisfaction, service quality and perceived value : An integrative model," vol. 1376, no. August, pp. 37-41, 2016.

[24] Sugiyono, Metode Penelitian Bisnis, Bandung: Alfabeta. 2013.

[25] H. Semuel and A. S. Lianto, "Analisis eWOM, brand image, brand trust dan minat beli produk smartphone di Surabaya,” J. Manaj. Pemasar., 2014.

[26] D. Dama, "Analysis of factors affecting interest buy consumers in selecting acer in lestari store manado," J. Berk. Ilm. Efisiensi, vol. 16, 2016.

[27] Recebido Aceito, "Brand relationships on retailing: the impact of image on behavioral intentions of consumers," 2011.

[28] M. D. Ambarwati, "Pengaruh citra merek terhadap minat beli," J. Adm. Bisnis, vol. 25, 2015. 